\title{
Influence of Integrated Nutrient Management on Flower and Seed Yield of African Marigold cv. 'Pusa Narangi Gainda' during Different Season in Mid Hills Condition of H.P.
}

\author{
Anju Kumari*, B.P. Sharma, Shweta Sharma and R.K. Gupta \\ Department of Floriculture and Landscape Architecture, YS Parmar University of \\ Horticulture and Forestry, Nauni, Solan (HP)- 173230, India \\ *Corresponding author
}

\section{A B S T R A C T}

K e y w o r d s
Tagetes erecta,
Azotobacter, PSB
(phosphorus
solubilizing
bacteria), PGPR
(Plant Growth
Promoting
Rhizobacteria), AM
(Arbuscular
mycorrhiza), NPK
and FYM
Article Info
Accepted:
15 August 2019
Available Online:
10 September 2019

The present investigation was carried out to find out influence of integrated nutrient management on flower and seed yield of African marigold cv. 'Pusa Narangi Gainda' during different season in mid hills condition of H.P, at Dr. Yashwant Singh Parmar University of Horticulture and Forestry, Nauni, Solan, HP in the year of 2016-2017 during different season (rainy season and summer season). The experiment was laid out in randomized block design replicated thrice and with 10 treatments. Study showed significant effect on flower yield per plant $(196.41 \mathrm{~g})$, flower yield per plot $(1767.63 \mathrm{~g})$, seed yield per plant $(10.88 \mathrm{~g})$ and seed yield per plot $(97.86 \mathrm{~g})$ in plants supplied with Azotobacter + PSB + 70\%RDF $\left(\mathrm{T}_{4}\right)$. With respect to season, higher flower yield per plant $(184.59 \mathrm{~g})$ and maximum flower yield per plot (1661.27 g) were recorded in plants being grown during summer season, however more seed yield per plant (17.28 g) and seed yield per plot $(155.52 \mathrm{~g})$ was observed during rainy season planting. Maximum seed weight of seed per head $(0.53 \mathrm{~g})$, highest number of seed per head $(186.51 \mathrm{~g})$ and 1000 seed weight $(3.37 \mathrm{~g})$ were recorded with $\left(\mathrm{T}_{3}\right)$ Azotobacter + PSB $+80 \%$ RDF during rainy season planting.

\section{Introduction}

Marigold (Tagetes erecta L.) is one of the most specially grown loose flower crop which belongs to family Asteraceae. Marigold has been named after 'Virgin Mary'. The king Curtez after conquering Mexico got fascinated by the beauty of marigold flowers and he carried it to Spain. It was then offered to the 'attar' of Virgin Mary and thus got its name Mary's gold which is now popularly known as marigold (Marshal, 1969). It is documented that French marigold (Tagetes patula L.) was put into cultivation in $1573 \mathrm{AD}$ and African 
marigold (Tagetes eracta L.) in 1596 AD in the Europe. In India, these were introduced by Portuguese between 1502 and 1550 (Gavhane et al., 2004). Marigold spreads quickly because of the facts that its cultivation is relatively easy, it has longer blooming period and beautiful flowers with a long shelf life. Also, the marigold flowers are utilized on commercial scale for different purposes. In India, about 278 thousand hectares area is presently under floriculture with a production of 1656 thousand MT loose flowers annually. The total area under marigold is 55.89 thousand hectares with a production of about 511.31 thousand MT. In Himachal Pradesh, it occupies an area of 22 ha with a production 19.61,000 MT (NHB 2016-17). Marigold is widely cultivated as bedding plant in landscape design.. The chemical fertilizers are important sources of nutrients but the indiscriminate use of chemical fertilizers poses the threat of environmental pollution and soil health degradation. At present, we are not in a position to abandon the use of chemical fertilizers completely, so the best option available is to use the biofertilizers in lesser amounts. Thus, integrated nutrient management is a strategy for advocating judicious and efficient use of chemical with matching addition of organic manures and biofertilizers. Therefore, emphasis is now focused on the use of organic manures such as farm yard manure, and bio-fertilizers like Azotobacter, Phosphate Solubilising Bacteria (PSB), AM fungi and PGPR (Plant Growth Promoting Rhizobacteria). Azotobacter is a non symbiotic bacterium which fixes atmospheric nitrogen in to soil (Somani, 2005). Phosphate solublizing organism are not only able to solubilize insoluble forms of inorganic $\mathrm{P}$ but are also capable to mineralize organic forms of $\mathrm{P}$, thus improving the availability of native soil P. Keeping the above facts in view, the present investigation was conducted with the objectives of to see the effect of biofertlizers and its combinations and to find out appropriate dose of biofertilizers on flower yield and seed yield during different season of African marigold respectively.

\section{Materials and Methods}

An experiment was conducted at the at the experimental farm of Department of Floriculture and Landscape Architecture, Dr. Yashwant Singh Parmar University of Horticulture and Forestry, Nauni, Solan, HP in the year of 2016-2017 to the Influence of integrated nutrient management on flower yield and seed yield of African marigold. African marigold cv. 'Pusa Narangi Gainda' was planted during different season i.e. rainy season and summer season respectively with the spacing of $30 \times 30 \mathrm{~cm}$ and with $1 \times 1 \mathrm{~m}^{2}$ plot size during 2016-2017. The experiment was laid out in randomized block design with three replications the experiment consisted of 10 treatments viz, $\mathrm{T}_{1} 100 \% \mathrm{NPK}$ of RDF, $\mathrm{T}_{2}$ $\begin{array}{lll}\text { Azotobacter+PSB+90\% } & \text { (RDF), } & \mathrm{T}_{3}\end{array}$ Azotobacter+PSB+80\% $\quad$ (RDF), $\quad \mathrm{T}_{4}$ $\begin{array}{lll}\text { Azotobacter+PSB }+70 \% & (\mathrm{RDF}), & \mathrm{T}_{5}\end{array}$ Azotobacter+AM+70\% $\quad(\mathrm{RDF}), \quad \mathrm{T}_{6}$ Azotobacter+AM+80\% $\quad$ (RDF), $\quad \mathrm{T}_{7}$ Azotobacter+AM+70\% $\quad(\mathrm{RDF}), \quad \mathrm{T}_{8}$ PGPR+90\% (RDF), $\mathrm{T}_{9} \mathrm{PGPR}+80 \%$ (RDF) and $\mathrm{T}_{10} \mathrm{PGPR}+70 \%$ (RDF). The data of both season were analyzed statistically for interpretation of results.

\section{Results and Discussion}

The pertaining data on flower and seed yield is presented in Table 1 clearly exhibited, maximum flower yield per plant (196.41 g) and maximum flower yield per plot (1767.63 g) recorded in plants grown with $\mathrm{T}_{4}$ (Azotobacter + PSB $+70 \%$ RDF), while these were minimum (127.62 and $1148.54 \mathrm{~g}$, respectively) with $\mathrm{T}_{1}(100 \%$ NPK$)$ during 2016-2017. The increased flower production might be due to that after application of organic manure and biofertlizers (Azotobacter and PSB) there was increase in plant growth 
as well as number of branches which directly stimulate flower yield per plant. These results are in close to conformity with the finding of Ajitkumar 2002 in Marigold and Maurya 2003 in Tuberose In contrast of season, more flower yield per plant (184.59 g) and flower yield per plot (1661.27 g) was noticed during summer season planting over rainy season planting. This could be attributed to the existence of congenial climatic conditions during the crop growth period and enabled them to produce increased amount of photosynthates and in turn resulted in more dry matter accumulation. Whereas, due to unfavorable climatic conditions existed during the rainy season planted crops, it failed to produce optimum vegetative growth and better flowering. Similar variation was also observed by Guruprasad (1999) and Nagarjun et al., (2004) in China aster; Chanda and Roychoudhary (1991) in African marigold. The application of different nutritional treatments significantly varied the seed yield per plant over the (5.86 g) $\mathrm{T}_{1}$ i.e. $100 \% \mathrm{NPK}$. Among these treatments, seed yield per plant $(10.88 \mathrm{~g})$ and seed yield per plot $(97.86 \mathrm{~g})$ to be recorded more with $\mathrm{T}_{4}$ (Azotobacter + PSB $+70 \%$ RDF) as compared to $\mathrm{T}_{1}(100 \% \mathrm{NPK})$, which might be due to the fact that beneficial effect of nitrogen (from the Azotobacter) and phosphorus (from PSB) on flower size and weight of individual flower attributed to increase the protein synthesis, thus promote the development of floral primordial, while phosphorus was found to be involved in formation of floral primordial resulting in more number of flowers obtained which directly affect the seed yield per plant.

Table.1 Influence of integrated nutrient management on flower and seed yield of African marigold during different planting seasons

\begin{tabular}{|c|c|c|c|c|c|c|c|c|c|c|c|c|}
\hline \multirow[t]{2}{*}{ Treatments } & \multicolumn{3}{|c|}{ Flower yield per plant (g) } & \multicolumn{3}{|c|}{ Flower yield per plot (g) } & \multicolumn{3}{|c|}{ Seed yield per plant (g) } & \multicolumn{3}{|c|}{ Seed yield per plot (g) } \\
\hline & $\begin{array}{l}\text { Rainy } \\
\text { Season }\end{array}$ & $\begin{array}{l}\text { Summer } \\
\text { Season }\end{array}$ & Mean & $\begin{array}{l}\text { Rainy } \\
\text { Season }\end{array}$ & $\begin{array}{l}\text { Summer } \\
\text { Season }\end{array}$ & Mean & $\begin{array}{l}\text { Rainy } \\
\text { Season }\end{array}$ & $\begin{array}{l}\text { Summer } \\
\text { Season }\end{array}$ & Mean & $\begin{array}{l}\text { Rainy } \\
\text { season }\end{array}$ & $\begin{array}{l}\text { Summer } \\
\text { season }\end{array}$ & Mean \\
\hline $\mathbf{T}_{1}$ & 103.81 & 151.42 & 127.62 & 934.26 & 1362.81 & 1148.54 & 9.10 & 2.62 & 5.86 & 81.87 & 23.58 & 52.73 \\
\hline $\mathbf{T}_{2}$ & 160.08 & 184.31 & 172.20 & 1440.75 & 1658.76 & 1549.76 & 12.33 & 4.22 & 8.28 & 110.97 & 37.98 & 74.48 \\
\hline $\mathbf{T}_{3}$ & 166.51 & 194.28 & 180.40 & 1497.96 & 1748.55 & 1623.26 & 14.74 & 4.27 & 9.51 & 132.66 & 38.40 & 85.53 \\
\hline $\mathbf{T}_{4}$ & 179.02 & 213.79 & 196.41 & 1611.18 & 1924.08 & 1767.63 & 17.28 & 4.47 & 10.88 & 155.52 & 40.20 & 97.86 \\
\hline $\mathbf{T}_{5}$ & 157.49 & 183.42 & 170.46 & 1417.38 & 1650.75 & 1534.07 & 12.23 & 3.96 & 8.10 & 110.10 & 35.64 & 72.87 \\
\hline$T_{6}$ & 165.78 & 189.79 & 177.79 & 1492.35 & 1708.11 & 1600.23 & 13.64 & 4.26 & 8.95 & 122.79 & 38.34 & 80.57 \\
\hline $\mathbf{T}_{7}$ & 172.97 & 210.44 & 191.71 & 1556.76 & 1893.93 & 1725.35 & 15.20 & 4.34 & 9.77 & 136.77 & 39.06 & 87.92 \\
\hline $\mathbf{T}_{8}$ & 154.93 & 181.85 & 168.39 & 1394.40 & 1636.68 & 1396.19 & 12.06 & 3.77 & 7.92 & 108.54 & 33.90 & 71.22 \\
\hline $\mathbf{T}_{\mathbf{9}}$ & 130.50 & 155.33 & 142.92 & 1186.47 & 1397.97 & 1411.58 & 9.77 & 3.10 & 6.44 & 87.96 & 27.87 & 57.92 \\
\hline $\mathbf{T}_{1}$ & 135.53 & 181.24 & 158.39 & 1219.74 & 1631.13 & 1425.44 & 11.67 & 3.47 & 7.57 & 105.03 & 31.26 & 68.15 \\
\hline Mean & 152.80 & 184.59 & 168.70 & 1375.15 & 1661.27 & 1518.20 & 12.80 & 3.85 & 8.33 & 115.22 & 34.62 & 74.92 \\
\hline $\mathrm{CD}_{0.05}$ & \multicolumn{2}{|c|}{$\begin{array}{l}\text { Season } \\
\text { Treatments } \\
\text { SeasonxTreatments }\end{array}$} & $\begin{array}{l}3.10 \\
6.94 \\
9.82\end{array}$ & \multicolumn{2}{|c|}{$\begin{array}{l}\text { Season } \\
\text { Treatments } \\
\text { SeasonxTreatments }\end{array}$} & $\begin{array}{l}28.05 \\
62.71 \\
88.69\end{array}$ & \multicolumn{2}{|c|}{$\begin{array}{l}\text { Season } \quad: \\
\text { Treatment } \quad: \\
\text { SeasonxTreatment : }\end{array}$} & $\begin{array}{l}0.81 \\
1.80 \\
2.54\end{array}$ & \multicolumn{3}{|c|}{$\begin{array}{lc}\text { Season } & : 7.27 \\
\text { Treatment } & : 16.26 \\
\text { Season xTreatments: } 23.00\end{array}$} \\
\hline
\end{tabular}


Table.2 Influence of integrated nutrient management on seed attributes of African marigold during different planting seasons

\begin{tabular}{|c|c|c|c|c|c|c|c|c|c|}
\hline \multirow[t]{2}{*}{ Treatments } & \multicolumn{3}{|c|}{ Number of seed per head } & \multicolumn{3}{|c|}{ Weight of seed per flower (g) } & \multicolumn{3}{|c|}{1000 seed weight $(g)$} \\
\hline & $\begin{array}{l}\text { Rainy } \\
\text { Season }\end{array}$ & $\begin{array}{l}\text { Summer } \\
\text { Season }\end{array}$ & Mean & $\begin{array}{l}\text { Rainy } \\
\text { Seasor }\end{array}$ & $\begin{array}{l}\text { Summer } \\
\text { Season }\end{array}$ & Mean & $\begin{array}{l}\text { Rainy } \\
\text { Season }\end{array}$ & $\begin{array}{l}\text { Summer } \\
\text { Season }\end{array}$ & Mean \\
\hline $\mathbf{T}_{1}$ & 172.66 & 68.40 & 120.53 & 0.43 & 0.15 & 0.29 & 2.69 & 2.59 & 2.64 \\
\hline $\mathbf{T}_{2}$ & 251.06 & 86.43 & 168.75 & 0.67 & 0.21 & 0.44 & 2.91 & 2.82 & 2.87 \\
\hline $\mathbf{T}_{\mathbf{3}}$ & 280.68 & 92.33 & 186.51 & 0.84 & 0.22 & 0.53 & 3.42 & 3.32 & 3.37 \\
\hline $\mathbf{T}_{4}$ & 260.47 & 106.69 & 183.58 & 0.73 & 0.25 & 0.49 & 3.41 & 3.30 & 3.36 \\
\hline $\mathbf{T}_{5}$ & 242.17 & 88.58 & 165.38 & 0.63 & 0.22 & 0.43 & 3.23 & 3.27 & 3.25 \\
\hline $\mathbf{T}_{6}$ & 233.84 & 75.07 & 154.46 & 0.61 & 0.20 & 0.41 & 3.20 & 3.23 & 3.22 \\
\hline $\mathbf{T}_{7}$ & 266.10 & 102.18 & 184.14 & 0.79 & 0.24 & 0.52 & 3.32 & 3.29 & 3.31 \\
\hline $\mathbf{T}_{8}$ & 191.39 & 69.04 & 130.22 & 0.51 & 0.16 & 0.34 & 2.78 & 2.70 & 2.74 \\
\hline $\mathbf{T}_{9}$ & 212.29 & 70.22 & 142.26 & 0.58 & 0.19 & 0.39 & 2.83 & 2.75 & 2.79 \\
\hline $\mathbf{T}_{10}$ & 205.84 & 70.65 & 138.25 & 0.57 & 0.19 & 0.38 & 2.83 & 2.75 & 2.79 \\
\hline Mean & 230.65 & 82.16 & 155.20 & 0.64 & 0.20 & 0.42 & 3.06 & 3.00 & 3.03 \\
\hline $\mathrm{CD}_{0.05}$ & $\begin{array}{l}\text { Season } \\
\text { Treatm } \\
\text { Season }\end{array}$ & atment & $\begin{array}{c}5.46 \\
12.44 \\
17.60\end{array}$ & $\begin{array}{l}\text { Seasor } \\
\text { Treatn } \\
\text { Seasor }\end{array}$ & atment & $\begin{array}{c}0.04 \\
0.09 \\
0.12\end{array}$ & $\begin{array}{l}\text { Season } \\
\text { Treatm } \\
\text { Season }\end{array}$ & tment & $\begin{array}{l}0.05 \\
0.12 \\
\text { NS }\end{array}$ \\
\hline
\end{tabular}

The similar results were recorded by Singh et al., (2015), Yadav et al., (2017) and Chandrikapure et al., (1999) in African marigold. In general, seed yield per plant and seed yield per plot was higher in rainy season (12.80 $\mathrm{g}$ and $115.83 \mathrm{~g}$, respectively) over summer season, which might attributed to there was lesser activity of pollinators during seed setting as well as shedding of seeds due to heavy rains at the time of harvesting during summer season planting as it is evident from meteorological data. These results are in the close conformity with the findings of Meena et al., (2015) and Singh and Arora (1998) in African marigold. As evident from Table 2, more number of seeds per head (186.51) noticed with the application of $\mathrm{T}_{3}$, (Azotobacter + PSB + 80\% RDF), while it was less (120.52) with $\mathrm{T}_{1}$ (control).
Maximum seed weight per head $(0.53 \mathrm{~g})$ was obtained with $\mathrm{T}_{3}$ (Azotobacter $+\mathrm{PSB}+80 \%$ $\mathrm{RDF})$, however it was minimum $(0.29 \mathrm{~g})$ in plants grown with $\mathrm{T}_{1}(100 \% \mathrm{NPK})$, which it is ascribed to the better quality in flower production traits by using chemical, manure, Azotobacter and PSB, which increased the nutritive status of macro and micro nutrients in soil.. The similar findings were also reported by Singh et al., (2015) in marigold cv. 'Pusa Bsanti' and by Bower et al., (1965) in petunia. Rainy season planting exhibited more number of seeds (230.65) per head, seed weight per head $(0.64 \mathrm{~g})$ and 1000 seed weight (3.06 g).however,1000 seed weight was recorded more $\left(3.37 \mathrm{~g}\right.$ with $\mathrm{T}_{3}$ (Azotobacter + PSB $+80 \%$ RDF). Similar results were also reported by Meena et al., (2015) in African marigold. 


\section{Interaction effect}

Interaction between season and treatments exhibited that that plants grown during summer season produced more flower yield per plant $(196.41 \mathrm{~g})$, flower yield per plot $(1767.63 \mathrm{~g})$ in plants grown with $\mathrm{T}_{4}$ (Azotobacter + PSB $+70 \% \mathrm{RDF})$ during summer season, while these were higher $(17.28,155.52 \mathrm{~g}$ respectively) in plants being grown in rainy season with the same treatment $\left(\mathrm{T}_{4}\right)$. More number of seed per head (280.68), highest seed weight per head $(0.84$ g) and maximum 1000 seed weight (3.37) were recorded with the application of $\mathrm{T}_{3}$ (Azotobacter $+\mathrm{PSB}+80 \% \mathrm{RDF})$ during rainy season.

\section{References}

Ajitkumar. (2002). Effect of organic and inorganic fertilizers on growth, yield and post harvest life of marigold. M.Sc. (Agri.) Thesis, University of Agriculture Science, Bangalore http://etd.usad.edu/ft/th8611.pdf.

Anonymous. 2016. National Horticulture Board. Department of Agriculture and Coperation, Government of India. Retrieved from www.nhb.gov.in.

Chanda, S and Roychaudhary, N. 1991. The effect of planting dates and spacing on growth, flowering and yield of African marigold (Tagetes erecta L.) cv. 'Siracole'. The Horticulture Journal 4(2): 53-56.

Chandrikapure, K.R., K.T. Sadawrte, D.M. Panchbhai and Shelke, B.D. 1999. Effect of bioinoculants and graded doses of nitrogen on growth and flower yield of marigold (Tagetes erecta L.). Orissa Journal of Horticulture 27(2): 31-34.

Gavhane, P.B., V.N. Kore, A.J.Dixit and Gondhali, B.V. 2004. Effect of graded doses of fertilizers and polythene mulches on growth, flower quality and yield of marigold (Tagetes erecta L.) cv. 'Pusa Narangi Gainda'. The Orissa Journal of Horiculture 32(1): 35-37.

Guruprasad, G.1999. Effect of time of planting on growth flowering and vase life studies in China aster (Callistephus chinensis Nees). M.Sc. (Agri.) Thesis, University of Agricultural Sciences, Dharwad.

Marshal, C. 1969. Encyclopedia of Gardening. Paul Hanyla, London. 20: 2213-2214.

Maurya, P.R. and Beniwal, S.V. 2003. Use of bio-fertilizers in horticulture crops. News Letter Agriculture and Biological Sciences 1: 12-13.

Meena, Y., H.S. Sirohi, B.S. Toma, and Kumar, S. 2015. Effect of planting time, spacing and pinching on growth and seed yield traits in African marigold (Tagetes erecta L.) cv. 'Pusa Narangi Gainda'. Indian Journal of Agricultural Sciences 85(6): 797-801.

Nagaraju, D., B.S. Reddy, R.T. Patil, P.M. Gangadharappa and Kulkarni, B.S. 2004. Effect of dates of planting on flowering and flower quality of China aster (Callistephus chinensis Nees.) cv. 'Kamini'. Journal of Ornamental Horticulture 7(3-4): 132-134.

Singh, J. and Arora, J.S. 1988. Effect of planting times and spacing on growth, flower and seed production of marigold cv. 'African Giant Double Orange'. The Punjab Vegetable Grower 23: 41-44.

Singh, K., U. Kumar and Kumar, A. 2015. Effect of planting date and spacing on performance of African marigold (Tagetes erecta L.) cv.'Pusa Narangi' under North Bihar agro-ecological conditions. International Journal of Forestry and Crop Improvement 6(1): 16-20.

Singh, L., P.K.S. Gurjar, A.K. Barholia, Haldar and Shrivastav, A. 2015. Effect 
of organic manures and inorganic fertilizers on growth and flower yield of marigold (Tagetes erecta L.) cv. 'Pusa Narangi Gainda'. Plant archives 15(2): 779-783.

Somani,L. L. 2005. Handbook of Biofertilizers. Agrotech Publishing Academy, Udaipur. 1167p.
Yadav, K.S., A.K. Pal, D.Yadav and Mauriya, S.K. 2017. Influence of different biofertilizers and its consortium on growth, flowering and seed yield of marigold. International Journal of Pure \& Applied Bioscience 5(6): 1660-1665.

\section{How to cite this article:}

Anju Kumari, B.P. Sharma, Shweta Sharma and Gupta, R.K. 2019. Influence of Integrated Nutrient Management on Flower and Seed Yield of African Marigold cv. 'Pusa Narangi Gainda' during Different Season in Mid Hills Condition of H.P. Int.J.Curr.Microbiol.App.Sci. 8(09): 241-246. doi: https://doi.org/10.20546/ijcmas.2019.809.029 